\title{
Limitations of Comparative Advertising Permissibility: Denigration/Disparagement
}

\author{
Jozef Andraško \& Soňa Ralbovská Sopúchová \\ Comenius University in Bratislava, Faculty of Law, Slovak Republic \\ jozef.andrasko@flaw.uniba.sk,sona.sopuchova@flaw.uniba.sk
}

ANDRAŠKO, Jozef \& RALBOVSKÁ SOPÚCHOVÁ, Soňa Limitations of Comparative Advertising Permissibility: Denigration/Disparagement. International and Comparative Law Review, 2016, vol. 16, no. 2, pp. 117-125. DOI: 10.1515/ iclr-2016-0018.

\begin{abstract}
Summary: The authors analyse legal regulation of comparative advertising that refers to situations when competitor's goods or services are expressly or by implication identified in any form of advertising. Such an analyse is made from the perspective of European Union, United States and Indian legal orders. In particular, the main focus is on the issue of denigration or disparagement as limitations of comparative advertising permissibility. In addition, significant case law with respect to aspects of denigration or disparagement within issue of comparative advertising is analysed. Such an analysis would lead to identification of differences that arose within comparison of various legal orders and case law. These findings are necessary in order to make a conclusion which approach regarding to the issue in question is the most preferable.
\end{abstract}

Keywords: comparative advertising, trade mark, denigration, disparagement, limitations.

\section{Introduction}

Comparative advertising (hereinafter "CA") refers to any form of advertising where competing goods or services are expressly or by implication identified. $\mathrm{CA}$ is considered as an important tool in promoting competition and transmission of information about goods and services to consumers. CA may refer to another's goods or services in positive or negative way. In the second case, where the competitor's goods or services are portrayed in negative light, it is the question of denigration or disparagement that can arise. Furthermore, this type of advertising strategy also involves use of trade mark without trade mark proprietor's consent what can be considered trade mark infringement and lead to disputes between competitors. Aforementioned situations can occur in different legal orders and courts can decide the dispute regarding to CA in different ways. Therefore, we decided to analyse the issue of denigration or disparagement as limitations of CA permissibility from the perspective of European Union (hereinafter "EU"), United States (hereinafter "US") and India. 


\section{Legislative Background}

We will focus on three different approaches regarding to regulation of CA, especially focusing on the meaning of "denigration" or "disparagement", in relation to advertisements and trade marks. First of all, we will analyse the EU legislation, secondly we will focus on the US approach and last but not least we will analyse very peculiar Indian approach.

\subsection{The EU Legislation}

The issue of CA is regulated by the Misleading and Comparative Advertising Directive 2006/114/EC (hereinafter "MCA Directive")1. MCA Directive contains the definition of the CA, in particular "comparative advertising means any advertising which explicitly or by implication identifies a competitor or goods or services offered by a competitor." 2 In other words, in the case when advertisement identifies a competitor or goods offered by him, we have to comply with the provisions of the MCA Directive. The CA is permitted because it can be very useful for the consumer, but only if the advertising is truthful, non-deceptive and some conditions are fulfilled. In the case of EU legislation these conditions are stated in the Article 4 of the MCA Directive. According to this article CA is permitted if those conditions are met. One of these conditions is situation when CA "does not discredit or denigrate the trade marks, trade names, other distinguishing marks, goods, services, activities or circumstances of a competitor."3

Discrediting is a form of denigration and since both are covered there is no need for further distinctions. However, not all of CA which discredit the trade marks of a competitor have to constitute discrediting within the meaning of this provision since any critical CA involves a certain discrediting of the competitor or his products. In the case of absolute prohibition, the intended liberalisation of CA would not be achieved. Therefore, only in cases where advertising unnecessarily discredits or denigrates the trade marks, trade names, products or activities of a competitor, should be considered unlawful. In particular, if CA emphasises the benefits of its own goods or service and reasonably shows the disadvantages of other competitor's product, this advertising is always permissible. On the other hand, a CA that only focuses on negative aspects of the competitor or his product is not acceptable. Discrediting can also result from an inappropriate and aggressive tone, an unobjective representation or valuation or even a unspecific, global rejection.

The CA to can be considered as legitimate when the competitor's trade mark or his reputation are respected. Furthermore, it cannot denigrate or make a

1 Directive 2006/114/EC of the European Parliament and of the Council of 12 December 2006 concerning misleading and comparative advertising.

2 Article 2(c) of the MCA Directive.

3 Ibid. Article 4(d). 
defamatory impression. Otherwise, the advertising will be considered unlawful under the provisions of the MCA Directive.

\subsection{The US Legislation}

The rules regulating CA in US legislation may be considered as very similar to those in the EU legislation. CA is subject to regulation through a combination of federal, state and local law, as well as self-regulatory codes of conduct.

Firstly, we can find a definition of CA in Statement of Policy Regarding Comparative Advertising published by the Federal Trade Commission (hereinafter "FTC") in 1979. According to this statement CA is "advertising that compares alternative brands on objectively measurable attributes or price, and identifies the alternative brand by name, illustration or other distinctive information." ${ }^{4} \mathrm{CA}$ is permitted if it is truthful and non-deceptive. US approach is very liberal because FTC states that advertisements that attack, discredit or otherwise criticize another product are permissible. Of course, advertisements have to comply with the provisions mentioned above. The list of conditions that have to be fulfilled like the one included in the Article 4 of MCA Directive is missing.

It is necessary to point out that advertising cannot discredit in a false way the competitor or competitor's goods or services. Section 43 (a) of the Lanham Act that is aimed at protecting trade mark prohibits any misrepresentation of the nature, characteristics, qualities or geographic origin of the advertiser's or another person's goods, services or commercial activities in CA. Under the Lanham Act, liability arises if an advertisement is either literally false or literally true or ambiguous, but is likely to deceive consumers because of an implied message. ${ }^{5}$

It could be helpful to mention that provisions of the National Advertising Division (hereinafter "NAD") ${ }^{6}$ applies higher standards to advertising that disparage a competitor's product because "claims that expressly or implicitly disparage a competing product should be held to the highest level of scrutiny in order to ensure that they are truthful, accurate and narrowly drawn."

Therefore, in the case of US legislation great attention is given to the concept of disparaging. More liberal approach of the US legislation, in comparison with the EU legislation, allows competitor to criticize other competitor's product. However, high level of scrutiny is used to ensure that the CA is in accordance with the provisions of the FTC, NAD and the Lanham Act.

$4 \quad 16$ CFR $\$ 14.15(c)$ FTC Statement of Policy Regarding Comparative Advertising.

515 U.S. Code $\$ 1125$.

6 National Advertising Division of the Council of Better Business Bureaus, Inc. is a self-regulatory agency that commands the respect of national advertisers, advertising attorneys, federal and state regulators and judiciary.

7 VILLAFRANCO, John, E. The Law of Comparative Advertising in the United States. IP Litigator, 2010, Vol. 16, No. 2, p. 1. 


\subsection{The Indian Legislation}

In the case of Indian legal framework clear statutory definition of CA is missing. The limitations to CA permissibility are regulated by two main acts, namely: Trade Marks Act (hereinafter "TM Act") and the Consumer Protection Act (hereinafter "CP Act"). ${ }^{9} \mathrm{CA}$ is permitted under some limitations and these limitations are particularly related to the term "disparagement". Because of missing legal definition of aforementioned term we have to use its dictionary meaning, where the term "disparagement" is understood as "to bring discrediting or reproach upon; dishonour; lower in esteem; speak on or treat slightingly or vilify; undervalue, and deprecate." 10

The CP Act states that disparagement of competitor's goods is considered as an unfair practice. Unfair practice is defined as trade practice which "for the purpose of promoting the sale, use or supply of any goods or for the provision of any service, adopts any unfair method or unfair or deceptive practice". With respect to disparagement, such a practice includes the practice of making any statement, whether orally or in writing or by visible representation which "gives false or misleading facts disparaging the goods, services or trade of another person"11 (previously part of $\$ 36$ of the Monopolies and Restrictive Trade Practices Act, 1969).

With respect to regulation of disparagement in TM Act, section 29(8) of the TM Act focuses on relation between disparagement and trade marks and states that " a registered trade mark is infringed by any advertising of that trade mark if such advertising:

(a) takes unfair advantage of and is contrary to honest practices in industrial or commercial matters; or

(b) is detrimental to its distinctive character; or

(c) is against the reputation of the trade mark."

The specific characteristic of the Indian legal framework regarding to CA is underlined by the Indian Court decision where was stated that a CA does not have to be truthful. Therefore, seller can declare false statements but he is not allowed to portray the competitor's product in a negative light, as we will explain in the next section. ${ }^{12}$

\section{Case Law}

In this section we briefly discuss the most significant case law in respect to $\mathrm{CA}$, in particular we focus on cases when courts had to resolve if the denigra-

8 The Trade Marks Act, 1999, No. 47 of 1999, 30th December, 1999.

9 The Consumer Protection Act, 1986, No. 68 of 1986, 24th December, 1986.

10 PATHAK, Akhileshwar. Legal Aspects of Business. New Delhi: Tata McGraw-Hill Education, 2007, p. 341.

11 Article 2 (1) r (1) x of CP Act.

12 Reckitt \& Colman Of India Ltd vs M.P. Ramchandran \& Anr; 199616 PTC 393. 
tion or disparagement as the CA restrictions can be applied. First of all, we will analyse one of the most important cases relating to denigration of competitor's trade mark, British Airways plc v. Ryanair Ltd (2001). ${ }^{13}$ Secondly, we will analyse U.S, EU and Indian case law focusing on issue in question.

\subsection{British Airways v. Ryanair}

One of the most important cases dealing with CA, especially the aspect of denigration is British Airways plc v. Ryanair Ltd (2001). ${ }^{14}$ Ryanair ran a CA campaign in various newspapers in the United Kingdom in 1999. The first advertisement is known as "Bastard" advertisement (headline "EXPENSIVE BA....DS!"), then later the "Expensive" advertisement (headline "EXPENSIVE BA"). The Bastard advertisement appeared in February and March, once in several national newspapers. The Expensive advertisement appeared just once in November, in the Evening Standard. British Airways plc (hereinafter "BA") has a registered trademark consisting of the letters BA registered for, amongst other services, air travel services. The Advertising Standards Authority (hereinafter "ASA") had upheld a complaint (made by members of the public) against the Bastard advertisement. ASA considered that the headline was likely to cause serious or widespread offence. Ryanair responded that it would not use the headline again. The second advertisement was the subject of an action for trade mark infringement and malicious falsehood.

Trade mark infringement and malicious falsehood falls within section 10(1) of the Trade Mark Act 1994, which corresponded with Art. 5 (1) (a) of the Council Directive 89/104/EEC of 21 December 1988 to approximate the laws of the Member States relating to trade marks (hereinafter "TM Directive 89/104"). ${ }^{15}$ According to section 10(1) of the 1994 Trade Mark Act „a person infringes the registered trade mark if he uses in the course of trade a sign which is identical with the trade mark in relation to goods or services which are identical with those for which it is registered." 16

Ryanair tried to protect itself saying that its advertisement falls within the defences provided by section 10(6) and/or section 11(2)(b) of the Trade Mark Act 1994. Pursuant to the first mentioned provision "nothing in the preceding provisions of this section shall be construed as preventing the use of a registered trade mark by any person for the purpose of identifying goods or services as those of the proprietor or a licensee. But any such use otherwise than in accordance with honest practices in industrial or commercial matters shall be treated as infringing

13 British Airways Plc v. Ryanair Ldt [2000] EWHC Ch 55 (25th October, 2000).

14 Ibid.

15 TM Directive 84/104 was repealed by Directive 2008/95/EC of the European Parliament and of the Council of 22 October 2008 to approximate the laws of the Member States relating to trade marks.

16 Section 10(1) of the Trade Mark Act 1994. 
the registered trade mark if the use without due cause takes unfair advantage of, or is detrimental to, the distinctive character or repute of the trade mark."17

The second defence, which corresponded with Art. 6. 1(b) of the Directive $89 / 104$, reads "A registered trade mark is not infringed by -

b) The use of indications concerning the kind, quality, quantity, intended purpose, value, geographical origin, the time of production of goods or of rendering of services, or other characteristics of goods or services, or [...]

Provided the use is in accordance with honest practices in industrial or commercial matters." 18

BA alleged that the individual price comparison and destination comparison made by Ryanair were misleading and therefore Ryanair's advertisement is not in accordance with honest practice in industrial and commercial matters as stated in section 10(6) of the Trade Mark Act $1994 .{ }^{19}$

Justice Jacob clarified what constitutes misleading advertisement. Furthermore, he established several important principles. First of all, he stated that the primary objective of the section 10(6) of the Trade Mark Act 1994 is to permit CA and that so long as the use of a competitor's mark is honest, there is nothing wrong in telling the public of the relative merits of competing goods or services and using registered trade marks to identify them. The test for honesty is objective based on whether a reasonable reader would say that the advertisement is not honest, given the full facts. Honesty has to be gauged against what is reasonably to be expected by the relevant public of advertisements for the goods or services in issue. Furthermore, it should be borne in mind that the general public are used to the ways of advertisers and expect hyperbole. The court will not analyse the content of advertisement word to word but will take more broad approach in recognition of the way that the majority of people would consider the advertisement. The advertisement must be considered as a whole. Justice Jacob ruled in favour of Ryanair that its comparative advertisements were in substance true and even if they could be offensive it did not infringe BA' s trade mark. Therefore, there is a defence under section10(6) and section 11(2)(b) of the Trade Marks Act 1994 and the malicious falsehood claim does not get off the ground. ${ }^{20}$

17 Ibid. section 10(6).

18 Ibid. section 11(2)(b).

19 BA had three complaints. The first one, it found Bastard headline offensive. The second one, it said that individual price comparisons were unfair. The last one, it said that the case of Frankfurt and Dinard the destination comparisons were unfair. Regarding to the offensive headline, Ryanair promised not to use it again. In the case of price comparison and the destination comparison Ryanair considered both comparisons to be fair.

20 Para. 30 of British Airways Plc v. Ryanair Ldt [2000] EWHC Ch 55 (25th October, 2000). 


\subsection{EU Case Law}

The issue of denigration of competitor arose in the case of Pippig v. Hartlauer, ${ }^{21}$ where Hartlauer (defendant) ran an advertising campaign by leaflets in which Pippig's (appellant) prices for frames with Zeiss lenses were directly compared with Hartlauer's prices in respect of the same brand of frames but with Optimed lenses. $^{22}$ The CJEU took the view that comparing prices cannot in itself entail the discrediting or denigration of a competitor who charges higher prices. Furthermore, the CJEU clarified that comparing rival offers, particularly comparing prices of products, is of the very nature of comparative advertising. ${ }^{23}$

Ryanair ran many comparative advertisement campaigns in different European countries. One of the most famous case is the one in Belgium, where the advertisements with text "Welcome Ryanair and its lowest fares. Goodbye Sabena and its outrageously expensive flights" appeared in newspapers. Ryanair refused to withdraw this advertisement and in addition, released an advertisement with a picture of the Brussels landmark the "Manneken Pis" a statue of a boy urinating, with the line "Pissed off with Sabena's high fares? Low fares have arrived in Belgium." Furthermore, Ryanair published price comparison. Sabena brought the case to court and claimed, besides others, that the advertisements were unlawful because the text was denigrating and damaging to Sabena's reputation. The Brussels Commercial Court held that Ryanair's comparative advertising campaign was misleading and offensive and damaged Sabena's reputation. ${ }^{24}$

\subsection{US Case Law}

Broadly speaking, US case law places a greater emphasis on the consumer's right to information and therefore its approach regarding to CA limits is more liberal. ${ }^{25}$ US courts recognize CA cases in relation to product disparagement that is also known as trade libel or slander of goods or services. Disparagement is considered any statement about a product or service of one company that is false and includes negative statements about these products or service. In addition, it can harm the reputation of a competitor. ${ }^{26}$ In Sylvania Case ${ }^{27}$ and National Refin-

21 Case C-44/01 Pippig Augenoptik GmbH \& Co. KG v Hartlauer Handelsgesellschaft mbH and Verlassenschaft nach dem verstorbenen Franz Josef Hartlauer [2003] ECR I-3095.

22 Ibid. para. 16.

23 Ibid. para. 80.

24 BARIGOZZI, Francesca and PEITZ, Martin. Comparative Advertising and Competition Policy. In CHOI, Jay Pil (ed). Recent Developments in Antitrust Theory and Evidence. The MIT Press: Cambridge, Massachusetts, London, England, 2007, p. 235-236.

25 Trade libel and product disparagement claims became actionable under the 1988 amendments to Section 43(a) of Lanham Act.

26 RUSTAD, Michael. Global Internet Law. West Academic. 2016, p. 452.

27 Smith-Victor Corporation v. Sylvania Electric Products, Inc., 242 F. Supp. 302 (N.D. Ill. 1965). In order to bring a suit for disparagement, the plaintiff must allege and prove that "(a) the statements referred to the plaintiff by name or the public knew that the statements referred to the plaintiff, and (b) statements were made by the defendant which disparaged 
ing $\operatorname{Case}^{28}$ court set out following three groups of statements that can be actionable for disparagement:

"1. Statements which referrer to the rival's goods and imputed to the rival's dishonesty or reprehensive business methods in connection with the goods;

2. Statements that relates to the quality of the goods without attributing dishonest or reprehensible business methods to the manufacturer; and

3. Alleged libelous statements that amount to no more than assertions by one tradesman that his goods are superior to those of his rival. ${ }^{\text {29 }}$

\subsection{Indian Case Law}

In the case of Reckitt \& Colman of India Ltd. v. Kiwi T.T.K. Ltd. ${ }^{30}$ an unnamed product of Reckitt (appellant) was disparaged as being ineffective and uneconomical in comparison to Kiwi (defendant) product. The Delhi High Court (Court) held that manufacturer is entitled to make a statement that his goods are the best and also make some statements for puffing of his goods but this should not disparage or defame the goods of another manufacturer. However, a manufacturer is not allowed portraying the other's product in a negative light. ${ }^{31}$

A similar situation arose in the case of Pepsi Company Inc. and Ors. vs. Hindustan Coca Cola ${ }^{32}$, wherein the Delhi High Court (Court) held that Coca Cola (defendant) disparaged Pepsi (appellant) products as the registered trade mark "PEPSI" was infringed. Furthermore, factors to decide the question of disparagement were formulated, namely: (i) Intent of commercial; (ii)Manner of the commercial; (iii) Story line of the commercial and the message sought to be conveyed by the commercial. ${ }^{33}$ The second factor is considered to be the crucial for deciding the disparagement. The Court stated that it is not actionable if the manner is only to show one's product better or best without derogating other's product. On the other hand, if the manner is to mock or to condemn other's product then it amounts to disparaging. ${ }^{34}$

\section{Conclusion}

Different assessments of the notions of the CA permissibility limitations, in particular denigration or disparagement in certain jurisdictions are consider-

the plaintiff or its product."

28 National Refining Co. v. Benzo Gas Motor Fuel Co., 20 F.2d 763 (8th Cir. 1927)

29 MERENSKI, Paul. et. al. Negative Comparative Advertising: A Legal Minefield. In Proceedings of the 1997 Academy of Marketing Science (AMS) Annual Conference. Springer Cham Heidelberg New York, Dordrecht, London, 1997, p. 336.

30 Reckitt \& Colman of India Ltd. v. Kiwi T.T.K. Ltd., 1996 (16) PTC 393.

31 Ibid. para. 12.

32 Pepsi Co. Inc. \& Ors. v. Hindustan Coca Cola Ltd, 2003 (27) PTC 305.

33 Ibid. para. 13.

34 Ibid. 
able. EU legal framework on the one hand stated in MCA Directive that the competitor and his product cannot be discredited or denigrated. On the other hand, there is obvious lack of CA harmonization in different member states. In the case of India, the absence of a clear definition in respect to the CA and disparagement leads to legal uncertainty. CA legislation is in the US subject to federal and state laws as well as self-regulatory codes, wherein disparagement is stipulated as CA restriction.

Several cases analysed the issues regarding to trademark infringement and malicious falsehood in CA. This issue also arose in British Airways v. Ryanair, where Justice Jacob decided that the use of registered trademark BA in CA was just the use of the mark in relation to the proprietor and while the advertisement amounted to vulgar abuse or may be considered offensive, the advertisement did not amount to trade mark infringement or malicious falsehood. This case clarifies how far competitors can go in CA when calling one competitor Bastards doesn't denigrate its trade mark.

In the light of analysed cases, we have to make an observation that denigration or disparagement as limits of CA permissibility are realized by CJEU, EU national courts, Indian courts and U.S courts. However, differences in applying laws regarding to subject are considerable. First of all, Indian case law limited CA to portray the other's product in a negative light and to mock or condemn other's product by competitor. Secondly, CJEU presented CA friendly approach, however different interpretations of applying the denigration requirement by national courts as the result of lack of CA harmonization is apparent. Last but not least, however US case law is more liberal towards CA, its case law recognizes statements used in CA under which the disparagement can be actionable.

Considering aforementioned legal frameworks and case law in respect to denigration or disparagement as limits of CA permissibility, we would like to make an observation on the most preferable approach. From our point of view, EU approach provides by MCA Directive clear legal definition of CA and an exhaustive list of its limits, precluding the application of stricter requirements in national legislation. However, EU case law can provide different interpretations of CA, in particular denigration, it is necessary to point out that this approach emphasizes the right of trade mark proprietors when balancing trade mark protection and the freedom of CA. 